\title{
Correlations Between Family Support with Coping Mechanisms in Patients with Chronic Renal Failure Undergoing Hemodialysis in Wijayakusuma Military Hospital, Purwokerto
}

\author{
$1^{\text {st }}$ Dwi Yulianti \\ Undergraduate Science of Nursing Student \\ Faculty of Health Science, Harapan \\ Bangsa University \\ Purwokerto, Indonesia \\ Email: yuliantidwi741@gmail.com
}

\author{
$2^{\text {nd }}$ Adiratna Sekar Siwi \\ Nursing Lecturer \\ Faculty of Health Science, Harapan Bangsa \\ University \\ Purwokerto, Indonesia \\ Email:adiratnasekarsiwi@uhb.ac.id
}

\author{
$3^{\text {rd }}$ Maria Paulina Irma Susanti \\ Nursing Lecturer \\ Faculty of Health Science, Harapan \\ Bangsa University \\ Purwokerto Indonesia \\ Email :mariapaulian@uhb.ac.id
}

\begin{abstract}
Chronic kidney disease occurs due to impaired kidney function that are progressive and settled. One of the treatment is hemodialysis that performed in a long period, causing changes in the physical, psychological, social, and the economic of the patient. These changes can affect the patient's coping mechanisms. This study aims to find the correlations between family support with coping mechanisms in patients with chronic renal failure undergoing hemodialysis in RST Wijayakusuma Purwokerto. The method of this study used correlative quantitative descriptive with cross-sectional approach. The sample obtained by using accidental sampling technique with a sample size as many as $\mathbf{9 4}$ respondents. Retrieving data used questionnaires ways of coping and family support. Analysis of the data used the frequency distribution and Spearman Rank. The result of this study showed that respondents with adaptive coping mechanism as many as $\mathbf{7 6}$ respondents and respondents who have received family support as many as 41 respondents. Statistical test results obtained by the value of $p$-value $=0.01$ was smaller than the value of $\alpha=0.05$ and $\mathbf{r}=0264$. In conclusion, there was a significant correlations between family support with coping mechanisms in patients with chronic renal failure undergoing hemodialysis with the direction of a positive correlations and the strength of weak ties.
\end{abstract}

Keywords: coping mechanisms, family support, hemodialysis

\section{INTRODUCTION}

Chronic renal failure or renal disease final stages (EndStage Renal Disease / ESRD) is progressive kidney tissue damage and loss of function, loss of the unit nephron and renal mass is reduced, with a worsening of progressive glomerular filtration, tubular secretion, and reabsorption [1].

According to the Global Burden of Disease (GBD) 2015, estimated that 1.2 million people died because of kidney failure, increased $32 \%$ since 2005 . In 2010, an estimated 2.3 to 7.1 million people with end-stage renal disease died without dialysis. Each year about 1.7 million people died because of acute renal failure. Overall 5-10 million people die every year due to kidney disease [2].

Data Basic Health Research in 2018, showed that the average proportion of patients with chronic renal failure in Indonesia that have or are undergoing hemodialysis in patients aged $\geq 15$ years is $19.3 \%$. The highest proportion are in the Province of Jakarta, Bali, and DIY around $38.7 \%$. The lowest is in Southeast Sulawesi Province by $2 \%$. The proportion of patients with kidney failure in the province of Central Java itself is approximately $16 \%$ [3].

Based on Indonesian Renal Registry (IRR) in 2016, showed that as many as $98 \%$ of patients with renal failure undergoing hemodialysis therapy, and $2 \%$ were undergoing peritoneal dialysis therapy. The biggest cause of chronic kidney disease are diabetic nephropathy (52\%), hypertension (24\%), congenital abnormalities (6\%), uric acid (1\%), lupus (1\%) and others [4].

Hemodialysis is a procedure which blood is removed from the patient's body and circulated in a machine outside the body called dialyzer. Hemodialysis uses the principles of diffusion of solutes penetrate the semipermeable membrane [5]. Patients undergoing hemodialysis in the long term will face a variety of problems, such as financial, difficulties to work, sexual desire decline, depression and fear of facing death, as well as the lifestyle that should be changed, to some extent affect the spirit of a person's life [6]. Measures hemodialysis can lead to a negative outlook, helplessness, hopelessness, lack of spirit to recover that make patients do maladaptive coping mechanisms [7].

Coping is an active process in which the use of the resources of the private and develop new behaviors that aims to cultivate the power of the individual, reducing the impact [7]. Renal failure patients who have good coping mechanisms will show hope of improvement a healthy condition and able to adapt the changes in physical, psychological, and social environment as a result of kidney failure that he suffered. Family support approach is needed in the management of therapy in patients with chronic renal failure undergoing hemodialysis [6].

The support that someone have can prevent the development of problems due to the pressures someone face. A person with high support more successfully to confront and overcome the problem than those who do not have support [8]. Based on the results of research [9] showed that the majority of respondents who have a high family support and adaptive coping mechanism that is 17 respondents (85\%). Results of research [10] about the coping strategies used by patients with chronic renal failure on hemodialysis showed that family support into categories stand out as an important psychological tool in the process of adaptation to stressful events brought by hemodialysis therapy. The family produces psycho-emotional support needed to overcome moments of tension and despair.

Based on the description above, the writer is interest to find the correlations between family support with coping mechanisms in patients with chronic renal failure undergoing hemodialysis in RST Wijayakusuma Purwokerto.

\section{METHOD}

The method of this study used descriptive quantitative with cross-sectional approach. This research was conducted in RST Wijayakusuma Purwokerto in June 2019. The population of this study were all patient with chronic renal 
failure undergoing hemodialysis in RST Wijayakusuma Purwokerto as many as 163 patients. The sample was conducted by using accidental sampling technique with a sample size as many as 94 respondents. The data was collected by using questionnaire of coping mechanisms and family support. The independent variable is family support and the dependent variable is coping mechanisms. Analysis of the data using frequency distribution and Spearman Rank test with significant level of 0,05 .

\section{RESULTS AND DISCUSSION}

This study obtained the following results : Table 1

Frequency Distribution of Respondents by Age of Respondents Chronic Renal Failure Undergoing Hemodialysis in Wijayakusuma Military Hospital Purwokerto $2019(\mathrm{n}=94)$

\begin{tabular}{cccc}
\hline Minimum-Maximun & Mean & Modus & Median \\
\hline $17-80$ year olds & $\begin{array}{c}49,18 \text { years } \\
\text { old }\end{array}$ & 49 years & 49 years \\
\hline
\end{tabular}

Table 1 shows that the average age of respondents is 49 years old. Respondents mostly aged of 49 years old as many as 7 respondents $(7,4 \%)$, the youngest respondents was 17 years old and the oldest one was 80 years old. The results are consistent with research [11] which shows that most respondents were 46 years old early in the study in which the youngest respondent was 32 years old and the oldest 70 years old.

Aged 40-70 years, glomerulus filtration rate will decline progressively to $50 \%$ of the normal, decline in the ability of the kidney tubules to reabsorb and gave the concentration of urine. Decreased ability for emptying the bladder completely thus increasing the risk of infection and obstruction and decreased fluid intake is a risk factor for kidney damage [12]. Results of research [13] also showed that the average age of respondents with chronic renal failure is 48 years old. Supported also by the results of research [14] showed that most respondents have a range of 35 to 65 years of age.

Researchers assumed that as someone get older the function of the systems or organs in the human body will be decreased. One of them is kidney, besides due to other factors that can worsen kidney function as lifestyle.

Table 2

Frequency Distribution of Respondents by Gender of Respondents Chronic Renal Failure Undergoing Hemodialysis in Wijayakusuma Military Hospital Purwokerto $2019(\mathrm{n}=94)$

\begin{tabular}{ccc}
\hline Gender & Number $(\mathbf{N})$ & Percentage $(\%)$ \\
\hline Male & 56 & 59.6 \\
Female & 38 & 40.4 \\
\hline Total & 94 & 100 \\
\hline
\end{tabular}

Table 2 shows that most of the respondents undergoing hemodialysis were male as many as 56 respondents $(59,6 \%)$, while female were 38 respondents $(40.4 \%)$. According to the assumptions of researchers, this is because male have tended habits or an unhealthy lifestyle such as smoking, drinking alcoholic beverages and a job that allows which should consume less healthy beverages.

In line with research [15] which showed that male respondents more than the female respondents as many as 60 respondents. According to [16] that male have a risk of developing the disease than female with chronic renal failure. This is because female has the hormone estrogen that can affect the levels of calcium in the body by inhibiting the formation of certain cytokines to inhibit osteoclast that is not excessive in resorb bone. Calcium has a protective effect by preventing the absorption of oxalate that can form kidney stones, which is one cause of chronic renal failure.

$$
\text { Table } 3
$$

Frequency Distribution of Respondents by Long of Undergoing Hemodialysis of Respondents Chronic Renal Failure Undergoing Hemodialysis in Wijayakusuma Military Hospital Purwokerto 2019 ( $\mathrm{n}=94)$

\begin{tabular}{ccc}
\hline Long of Undergoing Hemodialysis & Number $(\mathrm{N})$ & Percertage $(\%)$ \\
\hline$<1$ years & 74 & 78.7 \\
$2-4$ years & 19 & 20.2 \\
$5-7$ years & 1 & 1.1 \\
\hline Total & 94 & 100.0 \\
\hline
\end{tabular}

Table 3 shows that the respondents who undergoing hemodialysis mostly less than 1 year as many as 74 respondents (78.7\%). This study is in line with research [17] which shows that out of 50 respondents, 24 respondents had undergone hemodialysis for less than 1 year. The results of this study are not in line with research [18] which shows that the majority of respondents had undergone hemodialysis for $>2$ years of the 41 respondents from 60 respondents.

Researchers assumed that many respondents who undergoing hemodialysis whether less or more than 1 year depending on the distribution of respondents provided and sampled. Respondents who had undergoing hemodialysis $>1$ year tend to have more experience and knowledge about dialysis therapy undertaken.

Table 4

Frequency Distribution of Respondents by Family Support of Respondents Chronic Renal Failure Undergoing Hemodialysis in Wijayakusuma Military Hospital Purwokerto $2019(\mathrm{n}=94)$

\begin{tabular}{ccc}
\hline Family Support & Number (N) & Percertage (\%) \\
\hline Support & 41 & 43.6 \\
Not Support & 53 & 56.4 \\
\hline Total & 94 & 100.0 \\
\hline
\end{tabular}

Table 4 showed that most of the respondents does not have family support as many as 53 respondents $(56,4 \%)$, while respondent who have family support as many as 41 respondents $(43.6 \%)$. This study is in line with research [19] which showed that respondents who have not family support as many as 38 respondents from 62 respondents.

Researchers had assumed that many patients with chronic renal failure undergoing hemodialysis less family support during hemodialysis due to respondents already know the information related to hemodialysis. The results of the analysis of the questionnaire on question number 5 showed that the majority of states that families are often advised to consult a doctor as many as 43 respondents (45.7\%). Families are sometimes advised as many as 24 respondents $(25.5 \%)$. This suggests that the advice given by the family to the respondent to consult a doctor is not too important because the respondents have no awareness or have own initiative to do so.

This study was not in line with research [17] with the results of the 50 respondents, 33 respondents get family support. This is because respondents have a family that can be used as a source of support or a support system especially emotional support. 
but still have adaptive coping mechanisms. Respondents who

Table 5

Frequency Distribution of Respondents by Coping Mechanisms of Respondents Chronic Renal Failure Undergoing Hemodialysis in Wijayakusuma Military Hospital Purwokerto 2019 ( $\mathrm{n}=94)$

\begin{tabular}{lcc}
\hline $\begin{array}{l}\text { Coping } \\
\text { Mechanisms }\end{array}$ & Number (N) & Percentage (\%) \\
\hline $\begin{array}{l}\text { Adaptive Coping } \\
\text { Mechanisms }\end{array}$ & 76 & 80.9 \\
$\begin{array}{l}\text { Maladaptive } \\
\begin{array}{l}\text { Coping } \\
\text { Mechanisms }\end{array}\end{array}$ & 18 & 19.1 \\
\hline \multicolumn{1}{c}{ Total } & 94 & 100.0 \\
\hline
\end{tabular}

Table 5 shows that out of 94 respondents, 76 respondents $(80.9 \%)$ had an adaptive coping mechanism. This is in line with research [11] which showed that out of 39 respondents as many as 32 respondents have adaptive coping mechanisms. The adaptive coping mechanisms indicated by the respondents' attempt to try to talk with other people, trying to find more information about the problems being faced, connecting situation or problem that is being faced with spiritual such as the conduct of worship and prayer [11].

Coping refers to the constant changes a person's cognitive and behavioral efforts to manage the demands of the specific needs of both external and internal burdensome or exceeding one's resources [20]. Researchers assumed that adaptive coping mechanisms in this study is shown by the efforts of respondents receiving hemodialysis and accustomed to the action, feeling depressed a little or sometimes perceived by respondents when undergoing hemodialysis therapy. Respondents also continue to search for clues to pray and worship it better to God Almighty.

Table 6

Correlations Family Support with Coping Mechanisms in Patients with Chronic Renal Failure Undergoing Hemodialysis in Wijayakusuma Military Hospital Purwokerto $2019(\mathrm{n}=94)$

\begin{tabular}{|c|c|c|c|c|c|c|c|}
\hline \multirow{3}{*}{$\begin{array}{c}\text { Family } \\
\text { Support }\end{array}$} & \multicolumn{4}{|c|}{ Coping Mechanisms } & & & \multirow{3}{*}{$\begin{array}{c}\text { P- } \\
\text { Value }\end{array}$} \\
\hline & \multicolumn{2}{|c|}{$\begin{array}{c}\text { Adaptive } \\
\text { Coping } \\
\text { Mechanism }\end{array}$} & \multicolumn{2}{|c|}{$\begin{array}{l}\text { Maladaptive } \\
\text { Coping } \\
\text { Mechanism }\end{array}$} & \multicolumn{2}{|c|}{ Total } & \\
\hline & $\mathrm{n}$ & $\%$ & $\mathrm{n}$ & $\%$ & $\mathrm{n}$ & $\%$ & \\
\hline Support & 38 & 40,4 & 3 & 3,2 & 41 & 43,6 & 0,010 \\
\hline Not Support & 38 & 40,4 & 15 & 16 & 53 & 56,4 & $\mathrm{r}=0,264$ \\
\hline Total & 76 & 80,8 & 18 & 19,2 & 94 & 100 & \\
\hline
\end{tabular}

Table 6 shows that respondents who get a good family support with adaptive coping mechanism as much as 38 respondents $(40.4 \%)$, while respondents who earn a good family support with adaptive coping mechanism as much as 3 respondents $(3.2 \%)$. Respondents who do not get family support adaptive coping mechanism as much as 38 respondents $(40.4 \%)$, while respondents who have no family support with maladaptive coping mechanisms as much as 15 respondents $(16 \%)$.

Researchers assumed that the number of respondents who earn a good family support with adaptive coping mechanism due to the respondents would consider that the support and attention given to family members serve as a valuable support to form the character of the respondents were positive when faced with problems. The higher the family support the better the coping mechanisms of respondents.

There are patients who do not have the family support did not get the support of family/family support was not good and have adaptive coping mechanisms as much as 38 respondents (40.4\%). According to the assumptions of researchers, it because patients are able to receive a diseased condition while undergoing hemodialysis to control themselves when it does not have the support of the family.

Based on the theory advanced [21], how individuals in resolving a problem is determined by the individual's own resources such as physical health, positive outlook, problemsolving skills, social skills, social support, and the support material. Supported by the results of research [17] states that there are patients who have no family support who use coping mechanisms adaptive, this is because patients can receive pain conditions experienced and have the confidence or a positive outlook despite not getting support from family.

Supported by the research results [11], which indicates that there is a relationship between old patient suffering from chronic renal failure with coping mechanisms $(\mathrm{p}=0.015$ $<0.05$ ), the direction of a positive linear relationship means that the longer suffer from chronic kidney failure more adaptive coping mechanism patient. The longer a patient suffering from chronic renal failure means that more patients had various experiences stressor due to illness and the experience can be used as an anticipatory effort in the face of stressors experienced by the patient so that the patient can adapt to the conditions.

Based on the results obtained Spearman Rank p-value of 0.010 , where the value is less than the value of $\alpha$ is 0.05 and $r$ $=0.254$ thus $\mathrm{H} 0$ is rejected, which means there was a significant correlations between family support with coping mechanisms in patients with chronic renal failure undergoing hemodialysis in Wijayakusuma Military Hospital Purwokerto, direction of the correlations between family support and coping mechanisms have a positive correlations direction, but the level of connection strength is low. Researchers assumed that the relationship between family support with the coping mechanisms due to family support can affect the physical, psychological, social and patient. This is related to a family function is the function of affective and coping, socialization, health care, reproductive, and economic.

Family support is needed in the implementation of hemodialysis therapy undergoing by patients with chronic renal failure to increase self-confidence, giving comfort and security, and prevent the development of problems due to the pressures they face. An individual who has the support of high family will be more successful face problems compared to those without family support [8]. In line with the research [10] which was conducted using qualitative studies, interviews show support or media family to be a part of psychology that important in the process of adaptation to the stress that occurs because hemodialysis therapy.

\section{CONCLUSION}

1. The average age of respondents is 49 years.

2. Most of the respondents are male as many as 56 respondents $(59.6 \%)$.

3. Most respondents undergoing hemodialysis $<1$ year as many as 74 respondents $(78.7 \%)$.

4. The majority of patients have no family support or family support is not good, that as much as 53 respondents $(56.4 \%)$.

5. Most respondents use or have adaptive coping 
mechanisms as many as 76 respondents $(80.9 \%)$.

6. There was a significant correlations between family support with coping mechanisms in patients with chronic renal failure undergoing hemodialysis with the direction of a positive correlations and a low level at the strenght of correlations in Wijayakusuma Military Hospital Purwokerto.

\section{SUGGESTION}

1. For Hospital

Research results indicate a relationship despite the weak association level or lower can still be used as a reference for nurses in the hospital, especially nurses in hemodialysis to provide understanding and information about the importance of family support for the patient, as well as improve the quality of health services more comprehensive.

2. For Harapan Bangsa University

This study can be used as reference material for students of the University of Harapan Bangsa in increasing knowledge about family support, coping mechanisms, chronic renal failure, and hemodialysis.

3. For the Respondents

This study can be used as materials to improve knowledge and understanding of respondents on the importance of family support for the respondent to help solve any problems encountered and to improve relationships between family members.

4. For Further Researcher

Based on the research, it is known that there is a relationship between family support with coping mechanisms. Therefore, the researchers suggest analyzing the factors that affect the coping mechanisms and data retrieval with chronic renal failure patients undergoing hemodialysis would be better done before hemodialysis measures implemented.

\section{REFERENCES}

[1] G. LeMone, Priscilla., Burke, Karen., Bauldoff, Buku Ajar Keperawatan Medikal Bedah Gangguan Endokrin. Jakarta: EGC, 2018.

[2] V. A. Luyckx, M. Tonelli, and J. W. Stanifer, "The global burden of kidney disease and the sustainable development goals," Bull. World Health Organ., vol. 96, no. 6, pp. 414-422C, 2018.

[3] RISKESDAS, "Hasil Utama Riset Kesehatan Dasar 2018," Kementrian Kesehat. Republik Indones., 2018.

[4] Tim Indonesian Renal Registry, "9th Report Of Indonesian Renal Registry." Tim Indonesian Renal Registry, pp. 1-46, 2017.

[5] B. F. Tokala, L. F. J. Kandou, and A. E. Dundu, "Hubungan Antara Lamanya Menjalani Hemodialisis Dengan Tingkat Kecemasan Pada Pasien Dengan Penyakit Ginjal Kronik Di RSUP Prof. Dr. R. D. Kandou Manado," J. e-Clinic, vol. 3, no. April, 2015.

[6] Indanah, Sukarmin, and Rusnoto, "Kualitas Hidup Pasien dengan Gagal Ginjal," 7th Univ. Res. Colloqium 2018, pp. 608-615, 2018.

[7] Y. G. V Wurara, F. Wowiling, and E. Kanine, "Mekanisme Koping Pada pasien Gagal Ginjal Kronik yang Menjalani Terpi Hemodialisis Di Rumah sakit Prof.Dr.R.D Kandou Manado," Ejournal keperawatan, vol. 1, pp. 1-7, 2013.

[8] W. Suryaningsih.M, Kanine E, "Hubungan Dukungan Keluarga Dengan Depresi Pada Pasien Penyakit Ginjal Kronik Di Ruangan Hemodialisa BLU RSUP Prof. Dr. RD. Kandou Manado," ejournal Keperawatan (e-Kp), vol. 1, 2013.

[9] L. Dyanna, Yulia, I. Dewi, and Herlina, "Hubungan Dukungan Keluarga Terhadap Mekanisme Koping Pasien Post Operasi Mastektomi," Jom, vol. 2, no. 1, 2015.

[10] R. A. R. da Silva, V. L. de Souza, G. J. N. de Oliveira, B. C. O. da Silva, C. C. T. Rocha, and J. R. R. Holanda, "Coping strategies used by chronic renal failure patients on hemodialysis," Esc. Anna Nery - Rev. Enferm., vol. 20, no. 1, pp. 147-154, 2016.

[11] Y. Armiyati and D. A. Rahayu, "Faktor yang berkorelasi terhadap mekanisme koping pasien CKD yang menjalani hemodialisis di RSUD Kota Semarang," $J$. Muhammadiyah Semarang, 2013.

[12] A. R. B. Ali, G. N. M. Masi, and V. Kallo, "Perbandingan Kualitas Hidup Pasien Gagal Ginjal Kronik Dengan Comorbid Faktor Diabetes Melitus Dan Hipertensi Di Ruangan Hemodialisa Rsup. Prof. Dr. R. D. Kandou Manado," e-Jurnal Keperawatan (e-Kp), vol. 5, p. 9, 2017.

[13] B. Yucens et al., "The association between hope, anxiety, depression, coping strategies and perceived social support in patients with chronic kidney disease," Dusunen Adam, vol. 32, no. 1, pp. 43-51, 2019.

[14] T. H. R. Agustiyowati, R. Sitorus, A. Waluyo, and B. Besral, "the Lived Experience of Patients With PreDialysis Chronic Kidney Disease: a Qualitative Study," Belitung Nurs. J., vol. 4, no. 2, pp. 263-270, 2018.

[15] F. J. K and T. S. Bahri, "Perilaku Mengontrol Cairan Pada Pasien Hemodialisis," JIM FKEP, vol. III, no. 3, p. 7, 2018.

[16] W. Lestari, A. Asyrofi, and H. A. Prasetya, "Manajemen Cairan Pada Pasien Penyakit Ginjal Kronis Yang Menjalani Hemodialisis," J. Manaj. Asuhan Keperawatan, vol. 2, no. 2, pp. 20-29, 2018.

[17] A. Cumayunaro, "Dukungan Keluarga Dan Mekanisme Koping Pasien Gagal Ginjal Kronik Yang Menjalani Hemodialisa," vol. XII, no. 79, pp. 80-93, 2018.

[18] S. P. Dewi, D. C. Anita, and Syaifudin, "Hubungan Lamanya Hemodialisa dengan Kualitas Hidup Pasien Gagal Ginjal di RS PKU Muhammadiyah Yogyakarta," pp. 1-11, 2015.

[19] F. Mailani and R. F. Andriani, "Hubungan Dukungan Keluarga Dengan Kepatuhan Diet Pada Pasien Gagal Ginjal Kronik Yang Menjalani Hemodialisis," J. Endur. 2(3), vol. 2(3), no. October, pp. 416-423, 2017.

[20] K. Yodchai, T. Dunning, S. Savage, and A. M. Hutchinson, "The role of religion and spirituality in coping with kidney disease and haemodialysis in Thailand," Scand. J. Caring Sci., vol. 31, no. 2, pp. 359367, 2017.

[21] W. I. M. J. S. L. I. A. S. T. U. Suwartono, Buku Ajar Ilmu Keperawatan Dasar Buku 1, Buku 1. Jakarta: Salemba Medika, 2015. 